\title{
CRASTO DE PALHEIROS (MURÇA, NE PORTUGAL, 3RD - 1ST MILLEN- NIUM BC): FROM ARCHAEOLOGICAL REMAINS TO ORDINARY LIFE
}

\author{
ISABEL FIGUEIRAL ${ }^{(1)}$, MARIA DE JESUS SANCHES ${ }^{(2)} \&$ JOÃO LUÍS CARDOSO ${ }^{(3)}$
}

\begin{abstract}
:
The multidisciplinary study carried out at Crasto de Palheiros testifies to the local/regional importance of this site from the $3^{\text {rd }}$ to the $1^{\text {st }}$ millennium BC (Chalcolithic-Iron Age). Emphasis is on the overall picture obtained rather than on the specific data from each discipline. Food production is based on plant husbandry (wheat, barley, millet) and animal husbandry (cattle, goat/sheep and pig). Importance is given to the transformation of raw food into meals, based on the evidence from the material culture identified. A great level of continuity appears to have existed in the site from the $3^{\text {rd }}$ to the $1^{\text {st }}$ millennium in terms of consumed food products; however deep differences are noticed concerning their cultural integration.

Keywords: North-eastern Portugal, 3rd and 1st millennia B.C., settlement, diet, economy.

Resumo:

Crasto de Palheiros (Murça, NE Portugal, 3rd - 1st millennium BC): from archaeological remains to ordinary life. O estudo multidisciplinar desenvolvido no Crasto de Palheiros testemunha a importância local e regional deste sítio arqueológico desde o $3^{\circ}$ ao $1^{\circ}$ milenio AC (Calcolítico-Idade do Ferro). A ênfase é colocada no quadro geral obtido mais do que nos dados específicos de cada disciplina. A produção de alimentos é baseada no cultivo de plantas (trigo, cevada, milho) e criação de animais domésticos (bovinos, caprinos e suínos). Com base na evidência da cultura material identificada, é dada importância à transformação de alimentos crus em refeições. Do $3^{\circ}$ ao $1^{\circ}$ milénio, e em termos de produtos alimentares consumidos, parece ter existido no local uma acentuada continuidade; porém, notam-se diferenças profundas no que respeita à sua integração cultural.

Palavras-chave: Nordeste de Portugal, $3^{\circ}$ e $1^{\circ}$ milénio AC, povoamento, dieta, economia.
\end{abstract}

Received: 13 July, 2016; Accepted: 26 November, 2016

\section{INTRODUCTION}

The development of environmental archaeology has enabled us to reconstruct past environments and to study the day-to-day life of past human communities. Particular interest has been given to food residues as they provide information on what people ate and on how they lived. However, such data remain quite often cut-off, lacking integration with information from archaeological structures and artefacts, which is usually presented just as 'the archaeological background'.

This is why this "integrated" study is carried out at Crasto de Palheiros (north-eastern Portugal), where artefacts and ecofacts are considered as different aspects of a single unity, in the hope that we might go further than the more "classic" approach carried out for the monography of the site (SANCHES 2008). The premises of this work were first outlined (oral communication) in Montreal, at the AIA annual meeting 2006 (Session: The Archaeology of Food: culture and identity) but never published. The present manuscript combines the study of material vestiges and plant and faunal remains in this site allowing us to trace cultural changes and discuss possible changing patterns of human behaviour towards plants and animals.

\section{ENVIRONMENTAL BACKGROUND: PRESENT DAY ECOLOGY}

For the purpose of this work, the Eastern Trás -os-Montes region, in north-eastern Portugal, is defined as the area located east of the hills of $\mathrm{Pa}$ drela / Falperra and Burneira. It is included in the large geological unit Galicia - Trás-os-Montes, dominated mainly by metamorphic rocks, with granite only in the periphery areas (RIBEIRO 1974).

Two main morphologic-climatic areas are recognized: the high plateau of Miranda - Mogadouro and the Mirandela Bassin / or Tua region (TABORDA 1987). Crasto de Palheiros (Fig. 1) is located in this second area (CostA et al. 1998), which is at present included in the Mediterranean region, biogeographical province 'CarpetanoIbérico-Leonesa', sector 'Lusitano - Duriense'), with a climate varying from sub-humid humid to sub-humid dry. The distance to the ocean, altitude and exposition regulate the amount of rainfall. This is concentrated in the autumn - winter, which is an Atlantic influence, while the very dry summers are a Mediterranean characteristic (TABORDA 1987).

Concerning the spontaneous vegetation, this is of submediterranean type and includes arboreal species such as Quercus rotundifolia, Quercus faginea and Olea europaea (AGROCONSULTORES and COBA (ed.) 1991).

${ }^{1}$ ISEM, UMR 5554, CNRS, Univ. Montpellier, France; isabel.figueiral-rowe@inrap.fr

${ }^{2}$ Faculdade de Letras, Univ. Porto, CITCEM-FCT, Portugal ; mjsanches77@gmail.com

${ }^{3}$ Univ. Aberta, Lisboa, Portugal; Academia das Ciências de Lisboa ; cardoso18@netvisao.pt 


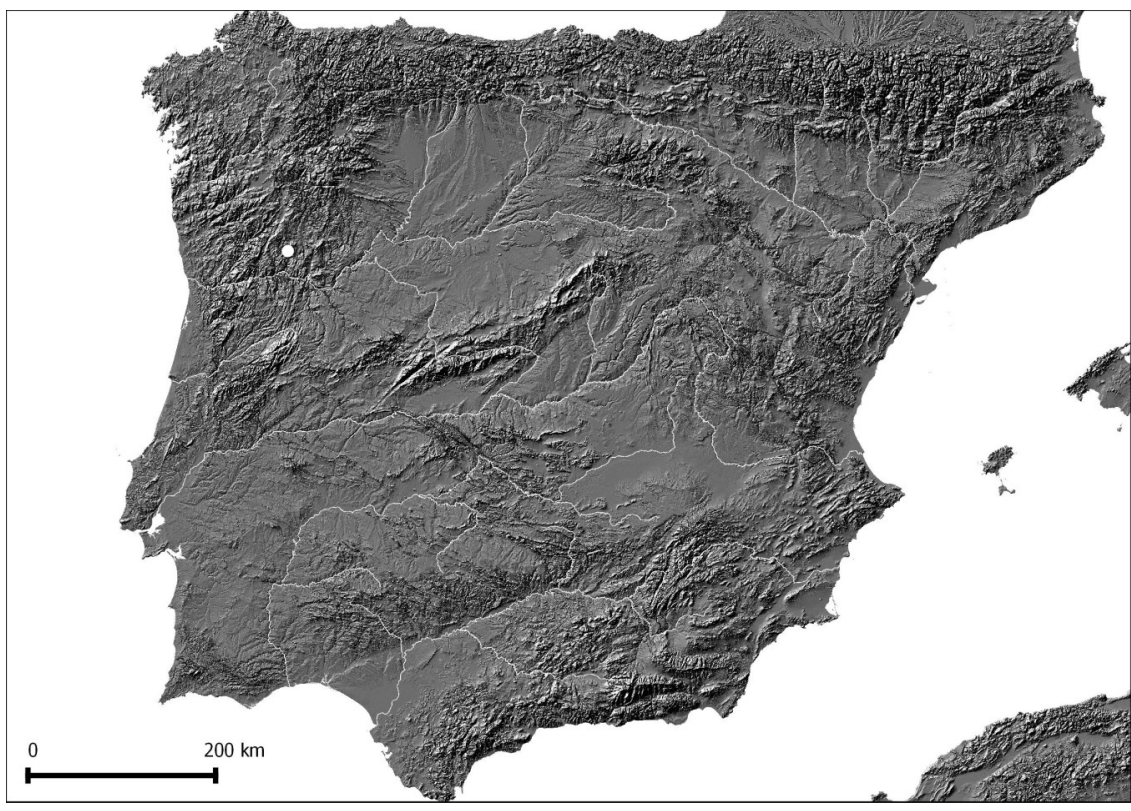

Fig. 1. Location of Crasto de Palheiros in the Iberian Peninsula - north-eastern Portugal.

Fig. 1. Localização do Crasto de Palheiros na Península Ibérica- Nordeste de Portugal. (The base map corresponds to a shaded relief of the Iberian Peninsula with the main outstanding rivers, made by Luís Luís from SRTM DEM 90 (JARVIS et al, 2008).

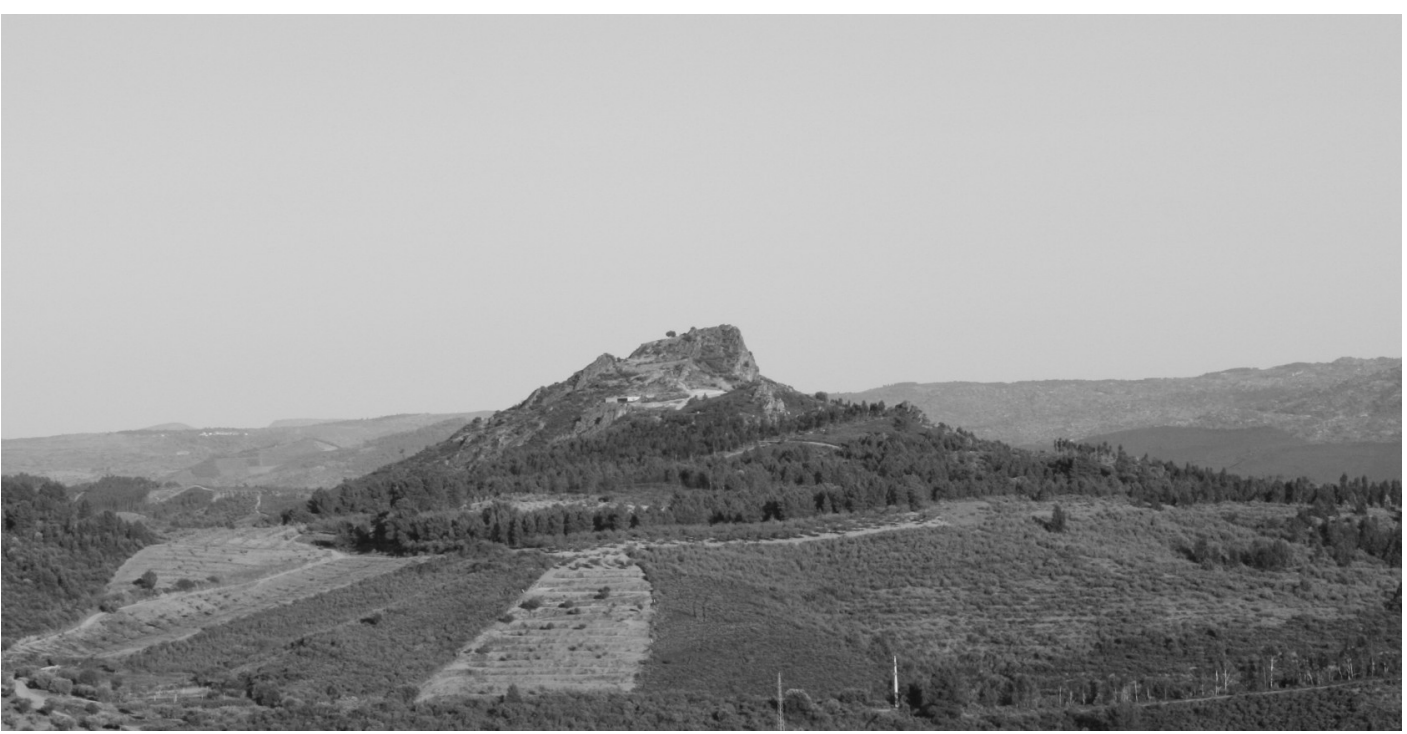

Fig.2. Crasto de Palheiros viewed from the North, with its Interpretive Center in the foreground.

Fig. 2. Crasto de Palheiros visto de Norte tendo o seu Centro Interpretativo em primeiro plano. 


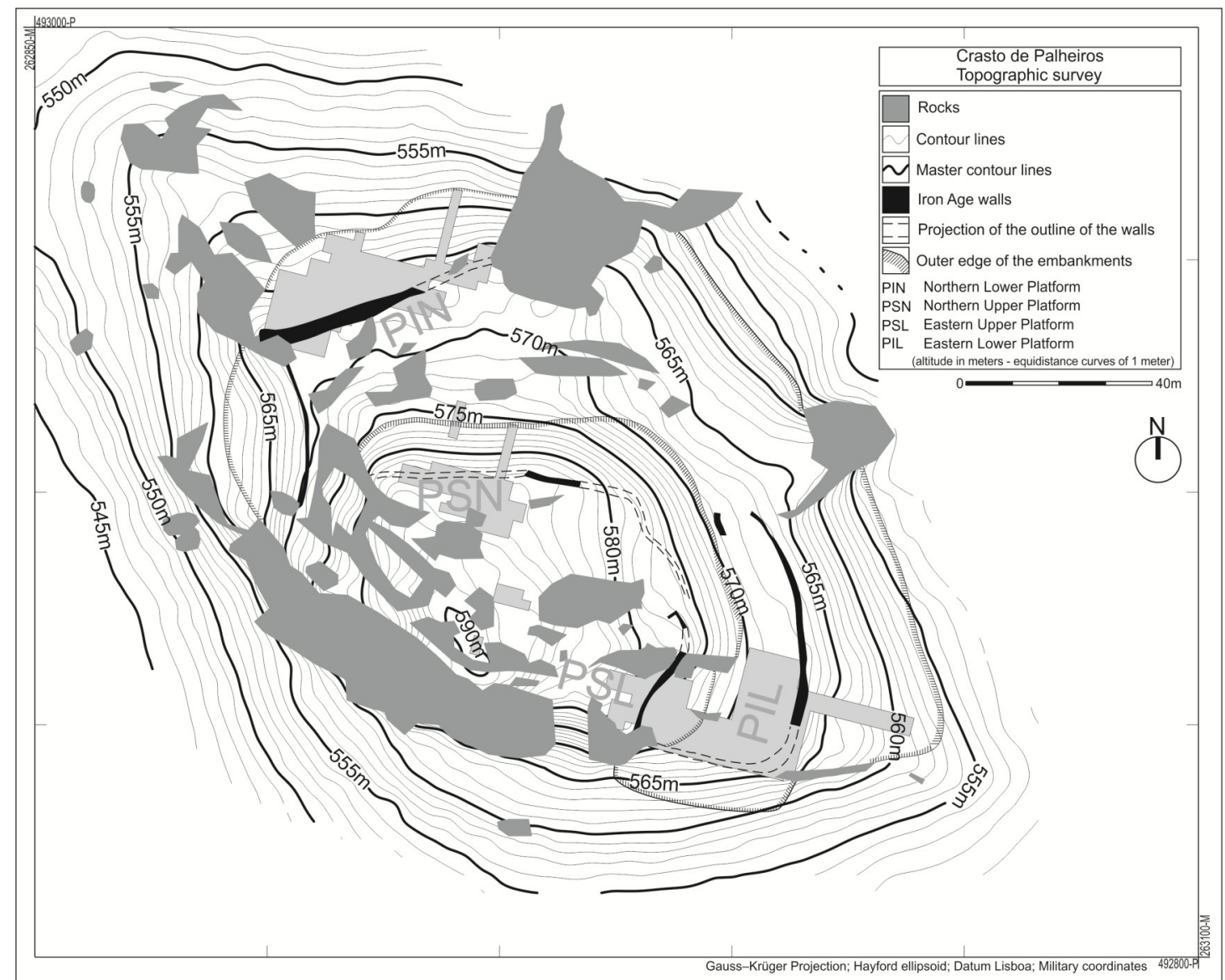

Fig. 3. Topographic Survey of Crasto de Palheiros site.

Fig. 3. Levantamento topográfico do Crasto de Palheiros.

\section{RESULTS}

\subsection{Main archaeological data}

Crasto de Palheiros is situated in a prominent hill top dominating the surrounding region (Fig. 1 and 2), and comprises two concentric platforms (Fig. 3). Stratigraphy points to the existence of two main episodes of occupation, one during the $3^{\text {rd }}$ millennium B.C., the other during the $1^{\text {st }}$ millennium B.C (Table 1).

Phase I belong to the $3^{\text {rd }}$ millennium B.C. $(2800$ -2200 BC: Chalcolithic) (SANCHES and PINTO 2008 a and $b$ ). This is the moment when gradual and planned construction work shapes the quartzitic hill top, transforming this natural outcrop into a large monument, thus becoming an example of mega-architecture. The building work, itself, is used as an "activity", a "scenario" and a "holder" of domestic, ritual / social activities. In terms of the regional settlement pattern, this is a distinctly different site, far too "monumental", displaying a wide range of activities and participating in an exchange network with smaller local sites of the Mirandela basin, like Navalho, Cemitério dos Mouros-Mirandela, Salto and Estirada-Murça (e. g. SANCHES 1997; 2016). It took c. 800 years for the settlement to reach its final shape.
It is obvious that during the $3^{\text {rd }}$ millennium the site was inhabited by a small community. However, it is also clear, that the purpose of such an original construction is far from being that of mere "habitation centre". Crasto de Palheiros appears to have been a regional "head-site", a place used by local and regional communities (in the lower Mirandela Basin) to manage and socially negotiate their communal life.

In terms of architecture, and in the beginning of the $3^{\text {rd }}$ millennium, the topmost area of the outcrop was surrounded by an embankment composed of sediments and stones, and by a clay wall, so that an upper dominating platform was formed. It is the upper precinct of the site (Fig. 3).

No substantial activities have been identified in this area. However, the use of Bell Beaker pottery (mostly the Maritime type) seems restricted to this upper platform, in contexts believed to have special social / ritual meaning (ANTUNES 1999; SANCHES 2016). Small stone structures, circular-, rectangular- or pentagonal-shaped might have been used for domestic purposes or otherwise.

It is possible that domestic activities were developed in the lower platform (without traceable structures), prior to c. $2700 \mathrm{BC}$ when the building of an outer embankment is started (Fig. 3). 
Table 1. Crasto de Palheiros: ${ }^{14} \mathrm{C}$ dates obtained concerning different constructive/occupation phases. [Calibration made according to Radiocarbon Calibration Program Rev. 4.3., based on STUIVER and REIMER, 1993.]

Tabela 1. Crasto de Palheiros: datas de ${ }^{14} \mathrm{C}$ relativas às diferentes fases construtivas/fases de ocupação.

\begin{tabular}{|c|c|c|c|}
\hline Phase & Lab. ref. & Radiocarbon date & Calibrated age $2 \sigma$ \\
\hline & & (14C yr B.P.) & (calendar yr B C - AD) \\
\hline \multirow[t]{9}{*}{ I } & CSIC-1218 & $4087 \pm 34$ & $2860-2496$ \\
\hline & UA-22884 & $4035 \pm 35$ & $2838-2465$ \\
\hline & UA-18528 & $4060 \pm 50$ & $2861-2467$ \\
\hline & Ua- 22212 & $4065 \pm 45$ & $2860-2470$ \\
\hline & CSIC-1617 & $4046 \pm 29$ & $2824-2472$ \\
\hline & Ua-23616 & $3895 \pm 50$ & $2466-2292$ \\
\hline & CSIC-1964 & $3950 \pm 42$ & $2580-2300$ \\
\hline & CSIC 1963 & $4129 \pm 42$ & $2880-2579$ \\
\hline & Ua-22213 & $3935 \pm 45$ & $2567-2292$ \\
\hline II & CSIC-1282 & $2686 \pm 43$ & $915-795$ \\
\hline \multirow[t]{14}{*}{ III (1-2) } & Ua-18526 & $2380 \pm 45$ & $758-385$ \\
\hline & CSIC-1962 & $2371 \pm 36$ & $727-693$ \\
\hline & CSIC-1219 & $2260 \pm 47$ & $401-144$ \\
\hline & CSIC-1961 & $2208 \pm 37$ & $380-190$ \\
\hline & Ua-18527 & $2195 \pm 50$ & $386-115$ \\
\hline & CSIC-1279 & $2045 \pm 35$ & $163 \mathrm{BC}-26 \mathrm{AD}$ \\
\hline & CSIC-1805 & $1982 \pm 30$ & $44 \mathrm{BC}-81 \mathrm{AD}$ \\
\hline & CSIC-1405 & $2014 \pm 26$ & $87 \mathrm{BC}-54 \mathrm{AD}$ \\
\hline & CSIC-1403 & $1954 \pm 26$ & $33 \mathrm{BC}-120 \mathrm{AD}$ \\
\hline & CSIC-1404 & $1951 \pm 26$ & $17-125 \mathrm{AD}$ \\
\hline & CSIC-1320 & $1979 \pm 32$ & $45 \mathrm{BC}-117 \mathrm{AD}$ \\
\hline & CSIC-1215 & $1959 \pm 47$ & $48 \mathrm{BC}-131 \mathrm{AD}$ \\
\hline & Sac-1970 & $2020 \pm 45 \mathrm{BP}$ & $129 \mathrm{BC}-71 \mathrm{AD}$ \\
\hline & Sac-1973 & $1980 \pm 50 \mathrm{BP}$ & $109 \mathrm{BC}-129 \mathrm{AD}$ \\
\hline
\end{tabular}

This outer embankment surrounds the whole of the domestic area, delimiting the lower precinct, and clearly establishes the architectonic separation with the exterior. Why was this structure built? Obviously, not to stop any further developments in the inside area. It would appear that it was the process of building in itself that mattered: building, readjusting and closure of certain structures which took more than 800 years. The archaeological record clearly shows that domestic and other subsistence activities took place here, linked not only with the construction and upkeep the structure, but also with social / ceremonial actions (SANCHES 2016).

Concerning domestic activities, habitation structures and artefacts similar to those of other open sites, such as small-medium sized decorated pots, are present. Their dimensions vary $(0,25-$ $30 \mathrm{~L}$ ), according to function: storage, preparation, consumption of food.

Local raw materials (quartz and granite) were used to fabricate knappers, axes, adzes and grindstones (MORAIS 2008), while other materials (variscite, flint, talc) and copper objects document regional / extra-regional contacts. In terms of site occupation, Crasto de Palheiros clearly represents a long-lasting (800 1000 years) investment in the economic activities and in the land (SANCHES 2016). However, it would however be difficult to label this site as a "normal sedentary settlement".

C. Palheiros was eventually abandoned during more than a thousand years and occupied again. It is possible that the site might have been used sporadically during this occupation hiatus, but remains identified so far are not conclusive.

Phase II, between 900/800-500 BC (Late Bronze Age) the settlement is not well characterized in the archaeological record because most traces were destroyed by later occupations (SANCHES and PINTO 2008a: 28; 2008b: 48).

Phase III concerns grosso modo the late $1^{\text {st }}$ millennium $\mathrm{BC}$ and the beginning of $1^{\text {st }}$ millennium $\mathrm{AD}$ (middle $5^{\text {th }} \mathrm{BC}-1^{\text {st }} 2 \mathrm{I}^{\text {nd }} \mathrm{AD}$ ) (SANCHES and PINTO 2005; 2008a and b).

Crasto III-1 (middle $5^{\text {th }}$ - middle $1^{\text {st }} \mathrm{AD}$ ) is an open settlement with circular / sub-circular huts, build with perishable materials, mainly with simple earthen ground. We have identified 5 discrete huts in the eastern lower platform: 1, 2, 3, 4 and 5 (Fig. 3 
and 4). The ground of some huts had been strengthened by fire and sometimes even paved. Fireplaces were present in all the huts excavated. The settlement was partially destroyed by fire, sometime during the end of the $1^{\text {st }}$ millennium $\mathrm{BC}$.

Its inhabitants appear to have farmed with hoe and plough. Few remains of axes and adzes, (in
Crasto III-1, III-2) (MORAIS 2008) contrast with the abundance of cultivated plants, and may reflect the adoption of plough farming.

The ceramic assemblage identified includes Attic pottery (just at the beginning of Crasto III-I), showing that this settlement was part of a trading network with the Mediterranean.

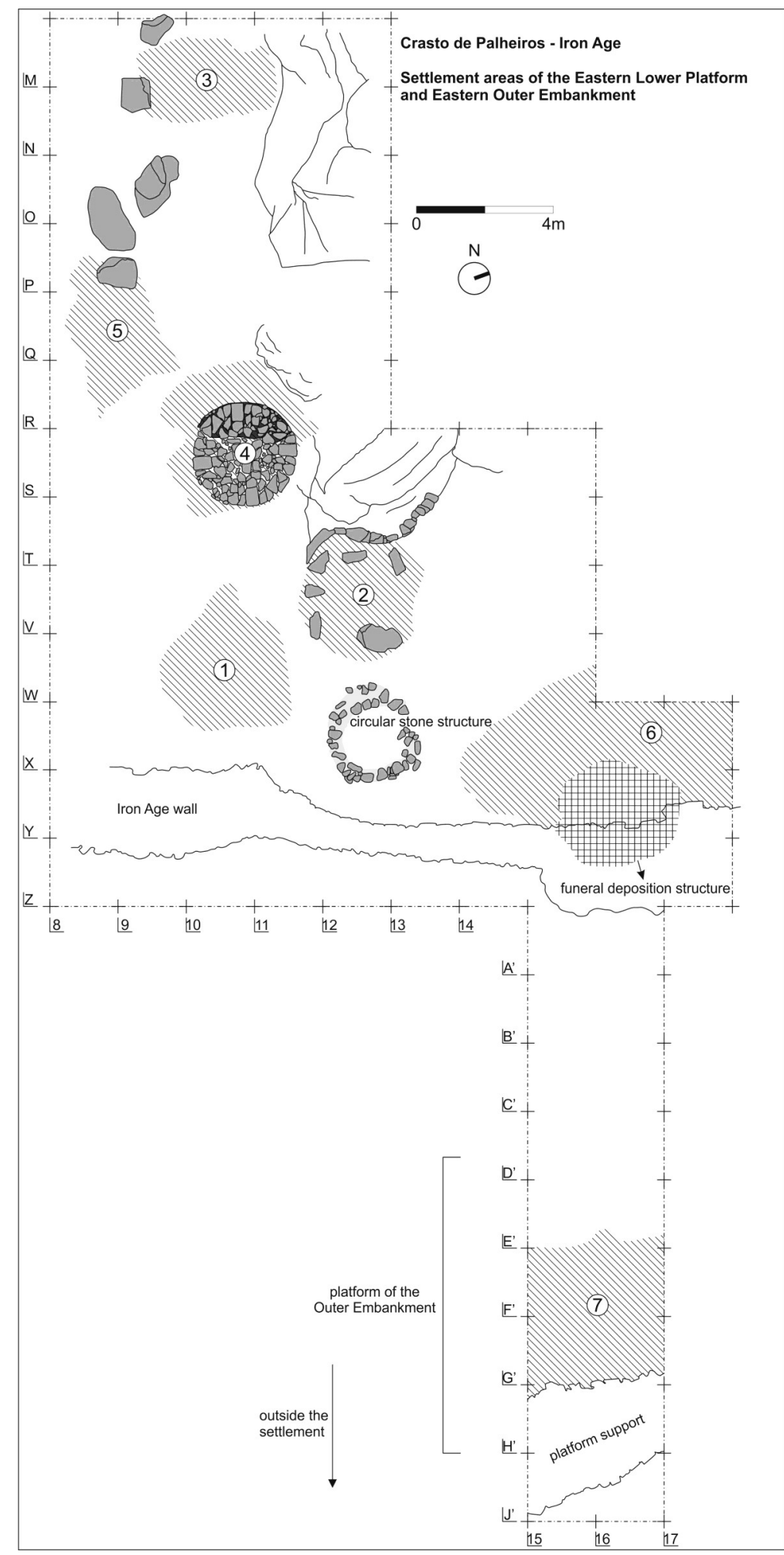

Fig. 4. Contexts of Iron Age remains. Eastern Lower Platform (Precinct L PIL): dwelling structures/huts 1, 2, 3, 4 and 5 [plus settlement Area 6 . Settlement area 7 is located in the Outer Embankment platform.]

Fig. 4. Contextos de recolha das amostras da Idade do Ferro. Plataforma Inferior Leste (Recinto L/PIL): unidades habitacionais 2, 3, 4 e 5 [mais a Área habitacional 6. A area habitacional 7 localiza-se na plataforma do Talude Exterior.] 
The identification of a double-mould (axe and knife), and the formal, esthetical and technical features of metal ornaments, and cauldron's constituents suggest on-site metal working, probably copper and bronze (SANCHES and PINTO 2005; PINTO 2008).

Crasto III-2 (late $1^{\text {st }}$ century AD) corresponds to the final phase of settlement occupation, with two concentric walls over the Chalcolithic stone bank surrounding the upper and lower platforms (Fig. 2 and 3). This occupation appears to have been short-lived (50-70 years). The living quarters occupied a much reduced space; huts are still made of perishable material, despite the fact that this occupation was influenced by the roman presencein the surrounding territory. Between middle $1^{\text {st }}$. middle $2^{\text {nd }}$ century $\mathrm{AD}$ the settlement was abandoned.

During the whole of phase III, pots used for food preparation, consumption and storage (AMORIM 1999; PINTO 2011) have been identified. Hand-made plain ware predominates, with only a few examples of fine wheel-turned vessels with impressed decoration. Grindstones are abundant (MORAIS 2008) as well as spindle whorls indicators of spinning and weaving (PINTO 2011). In addition, copper and bronze artefacts (ornaments, cauldrons and tools) are also abundant (PINTO 2008).

\subsection{Data from seeds and fruits}

Exhaustive sampling of sediments inside the structures excavated (referred to as habitation units) was carried out during field work and flotation of these sediments allowed us to recover the organic material using a $0,4 \mathrm{~mm}$ mesh sieve. For full details on sampling procedures please see SANCHES (2008, Eds).

Large concentrations of seed and fruit remains were found but none in connexion with the $3^{\text {rd }}$ millennium occupation. In fact relatively few remains were recovered in the samples from this period (Table 2) and the chronology of some of these remains may have to be reconsidered as we will mention later on. The analysis of these remains allowed us to identify barley (Hordeum vulgare var vulgare and Hordeum vulgare var nudum), wheat (Triticum dicoccum and/ or Triticum spelta), broomcorn millet (Panicum miliaceum) and Pea (Pisum sativum). Wheat appears to be the most frequent and abundant cereal. As noticed by the nomenclature used, the distinction between Triticum dicoccum and Triticum spelta was not always carried out. In fact, the difference between these two species can only be convincingly achieved when the spikelet is available. In the first phase of our study (FIGUEIRAL and SANCHES 2003) only typical grains and spikelet elements of Triticum dicoccum were found. Spikelet elements of Triticum spelta were only detected in samples studied later on. However, as the first samples had not been sorted in their entirety (due to amount of material) it was impossible to know whether Triticum spelta spikelets might have been found had we continued. This is why we decided to change the nomenclature of our first identifications (concerning the caryopses) and use instead the more conservative Triticum dicoccum and / or Triticum spelta.

Cultivated legumes include broad bean (Vicia faba) and pea (Pisum sativum). Collection of Arbutus and juniper berries as well as olives (Olea) is also noticed. The identification of Olea is particularly interesting, as it may testify that the wild olive grew in the region.

During the $1^{\text {st }}$ millennium plant diet appears to have been based largely on the consumption of cereals, as shown by the very abundant remains recovered (Table 3), especially in the Lower Eastern Platform, where habitation units 1, 2, 3 and 4 are located.

The large concentrations sampled in the Lower Eastern Platform are composed mainly of wheat grains: emmer (Triticum dicoccum) and-or spelt (Triticum spelta); Hulled barley (Hordeum vulgare) and broomcorn millet (Panicum miliaceum) are also present. The presence of Setaria is also possible, but identification is inconclusive.

Wheat and barley chaff had been separated before storage. Only millet was kept in its husks, as testified by the remains from units 1 and 2. This may have been a current practice as, when cleaned, millet grains quickly turn sour (SIGAUT 1988). The near absence of weed seeds supports the hypothesis that crops had already been cleaned.

Wheat is the only cereal recorded in all areas; Barley is noted in three of the areas, while millet is only present in the Lower Eastern Platform. Estimated amounts of cereal types suggest that emmer wheat was predominant.

During this phase, cereals were complemented by legumes, such as broad bean (Vicia faba). Concerning recollection it is difficult to estimate its role in everyday life. For the moment only the collection of Arbutus berries and pine kernels is recorded during this period. The absence of acorns may be considered as surprising as the use of their flour for bread making was widespread among local populations (RODRÍGUEZ LÓPEZ et al. 1993, among others). However, this does not mean that they were not currently harvested, both for human and animal consumption.

In short, remains studied testify to the cultivation of a variety of crops (1) hulled wheat and barley, broomcorn millet and broad bean are apparently present during both the $3^{\text {rd }}$ and $1^{\text {st }}$ millennia, (2) naked barley and pea are also identified during the $3^{\text {rd }}$ millennium, (3) on the whole wheat appears to be the most frequent and abundant cereal in both occupation moments. 


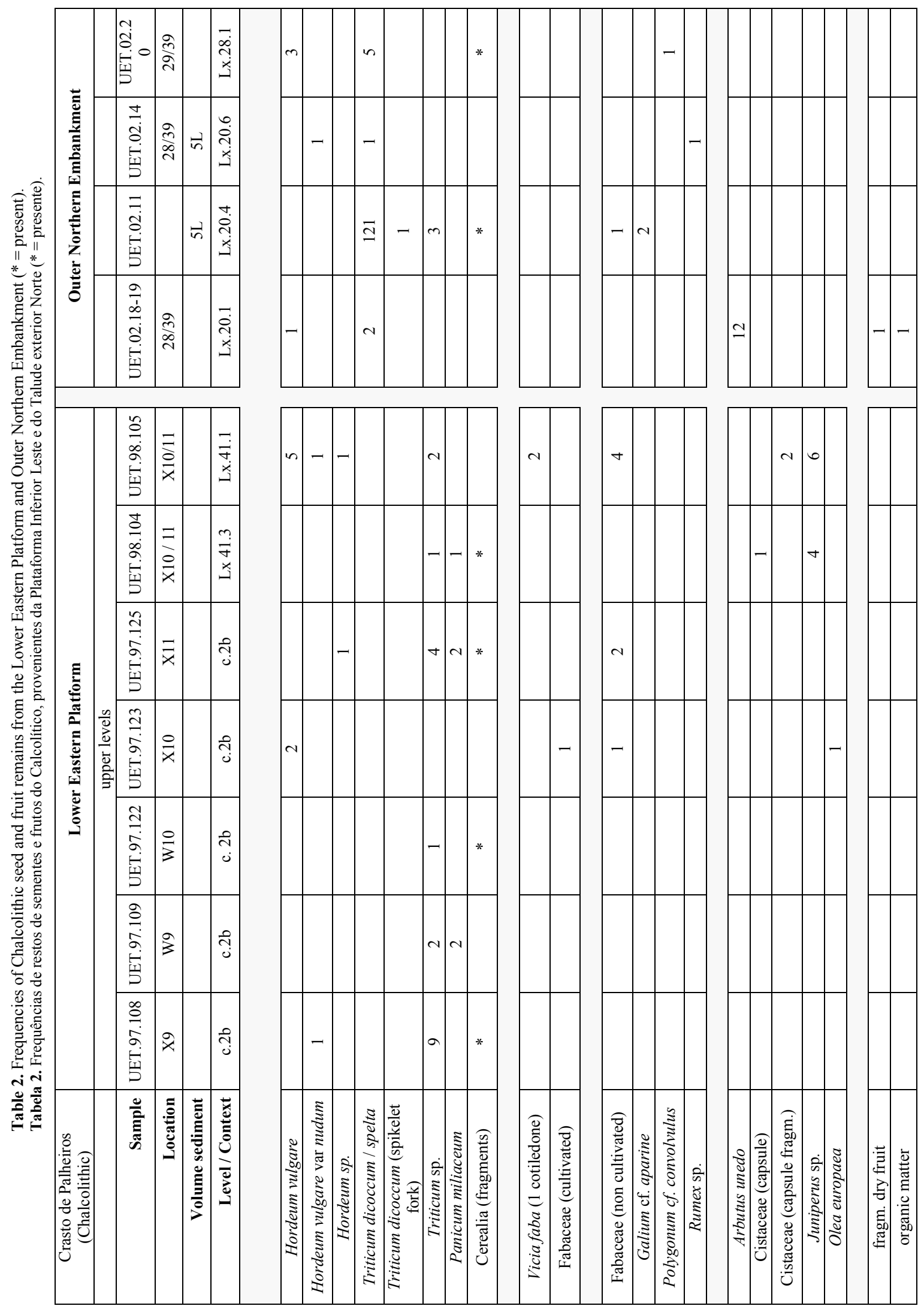




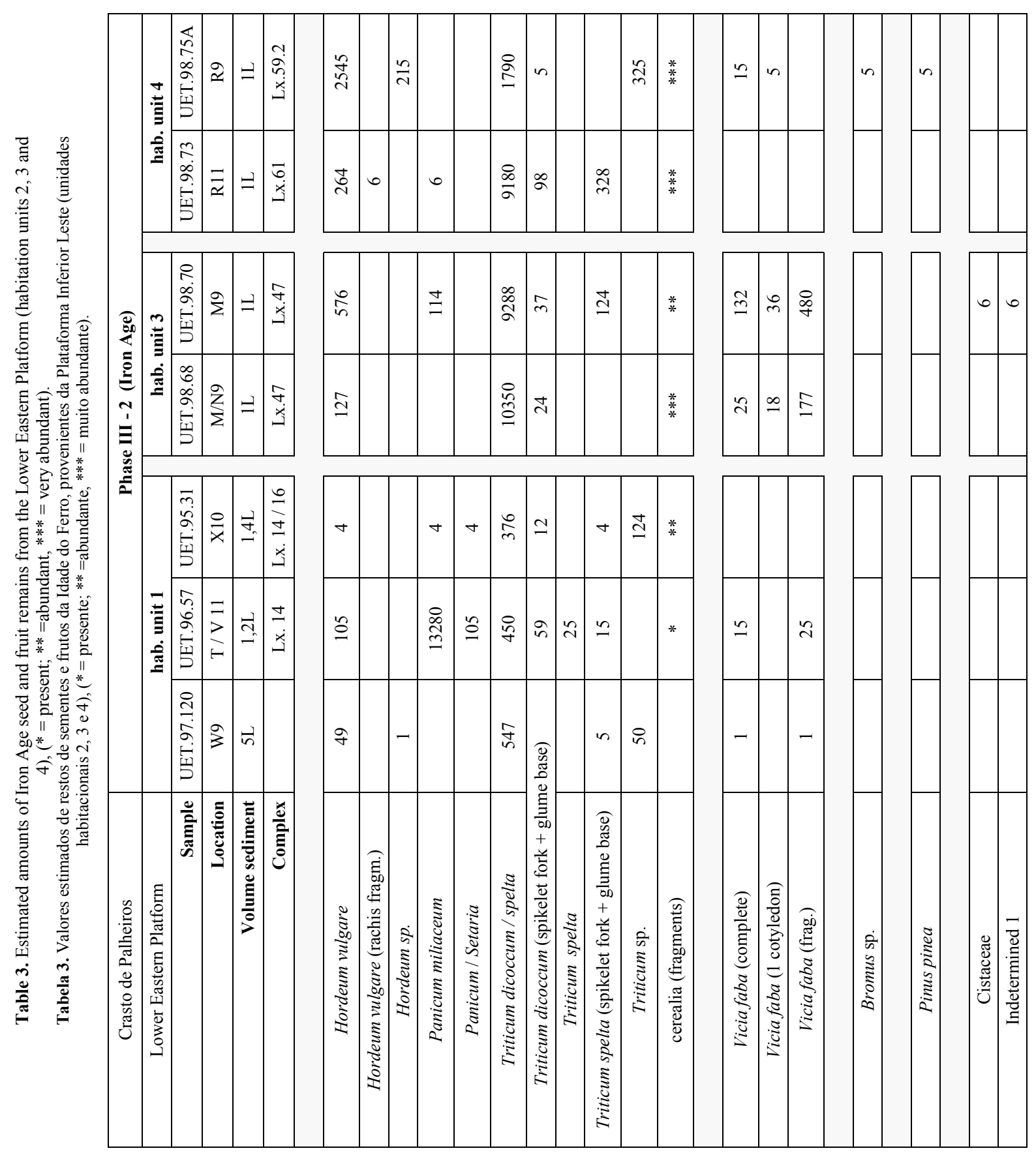


The association Triticum dicoccum and Hordeum vulgare is routinely observed in sites from the Eastern Mediterranean (Hopf 1987) and continental areas from northern Iberia (BUXÓ i CAPDEVILA et al. 1997). Concerning the Iberian Peninsula, in general, the importance of Triticum diccocum appears to have declined from the Calcolithic on, while the weight of Hordeum vulgare increases during the Iron Age (BuXÓ 1997; BuXó i CAPDEVILA et al. 1997).

The identification of Triticum spelta (spiklets) and Panicum miliaceum as early as the $3^{\text {rd }}$ millennium may be considered problematic and could eventually suggest bioturbation; some remains could in fact belong to the $1^{\text {st }}$ millennium occupation as they were recovered from samples taken near a possible animal burrow; Doubts concerning this chronology had already been raised by other authors (TERESO et al. 2013). Only the new $14 \mathrm{C}$ dates, which will be available soon, will allow us to elucidate this issue.

But regardless of their chronology the identification of these two species is interesting for other reasons. Triticum spelta is a resistant species which adapts well to cold weather and thin mountain soils, and is still cultivated in a traditional way by farmers from the Basque country and Asturias (PEÑA Chocarro 1992, 1995). Its presence in northern and northwestern Iberia has been recorded in numerous Iron Age sites (BURILlO 1983; CUBERO 1994; BuXó and ECHAVE unpublished and cited by BUXÓ et al. 1997, REY CASTINEIRA et al. 2011, SEABRA 2015). At Palheiros, the cultivation of Triticum spelta and Triticcum dicoccum, rather than free-threshing wheat (easier to process but requiring rich soils), may result from local environmental conditions; these two glume wheats would adapt easily to poor soils. Hulled barley is also tolerant of poor soils (ZOHARY and HoPF 2004, BuXÓ et al. 1997).

Panicum miliaceum, on the other hand, adapts well to different ecological conditions (ZOHARY and HOPF 2004) and can be used as a 'replacement' crop. Sown in the spring, it can replace a failed winter crop. As far as we know, other finds of Panicum in northern Portugal include: Crasto das Ermidas $\left(1^{\text {st }}\right.$ c. A.D., V. N. Famalicão, Ede, unpublished report cited by QUEIROGA 2003), Crasto do Crastoeiro (early Iron Age, Mondim de Basto, PINTo da Silva 1988, SEABra 2015), Chã (2 $2^{\text {nd }}$ B.C. - $1^{\text {st }}$ A.D., Cerejais, Alfandega da Fé) (VAZ et al. in press).

\section{2. Data from fauna remains}

Very few identifiable fauna remains were recovered in the c. 200 samples available due to both soil acidity and cooking transformation. As a result it has been impossible to estimate the minimum number of specimens. Data obtained are summarized in table 4 . No qualitative changes are noticed from the $3^{\text {rd }}$ to the $1^{\text {st }}$ millennium.

Table 4. Data from faunal remains (** = abundant). Identifiable fragments of: Cattle (include skull and carpus); Caprinae (include scapula, ribs, humerus, radius and phalanges); Suidae (include lateral phalanges). Restos faunísticos (** = abundante).

Tabela 4. Fragmentos identificáveis de: Bovídeos (inclui crâneos e carpos); Caprideos (inclui escápula, costelas, úmero, rádio e falanges); Suídeos (inclui falanges laterais).

\begin{tabular}{|c|c|c|}
\hline Crasto de Palheiros & & \\
\hline \multicolumn{3}{|l|}{ Fauna remains } \\
\hline & Chalcolithic & Iron Age \\
\hline \multicolumn{3}{|l|}{ Bos taurus } \\
\hline teeth & 12 & 16 \\
\hline identifiable bone fragments & 3 & 4 \\
\hline unidentifiable fragments & 19 & 9 \\
\hline \multicolumn{3}{|l|}{ Ovis / Capra } \\
\hline teeth & 9 & 5 \\
\hline identifiable bone fragments & 12 & 2 \\
\hline unidentifiable fragments & $* *$ & $* *$ \\
\hline \multicolumn{3}{|l|}{ Sus sp. } \\
\hline teeth & 2 & 2 \\
\hline identifiable bone fragments & 1 & 0 \\
\hline unidentifiable fragments & 0 & 0 \\
\hline
\end{tabular}

Remains identified indicate de presence of Cattle, Ovicaprids and Suidae in both occupation moments (CARDOSO 2005).

Cattle (Bos taurus) appears to be the most abundant species in terms of number of remains. These include parts of long bones, which present signs of having been exposed to fire, skulls, carpus and teeth. Vertebrae and ribs are absent, which may be a result of a taphonomic bias. The animals were killed at different stages of growth; senile specimens are however absent.

The second most abundant taxon is Ovis / Capra. Remains identified are composed of fragments of scapula, ribs, humerus, radius and phalanges. Vertebrae are absent. Small sized specimens were also butchered at different stages of growth

Sus is the third taxon in terms of number of identified remains. Unfortunately it was impossible to distinguish the domesticated from the wild form (Sus scrofa domesticus / Sus scrofa). The characteristics of dental elements and lateral phalanges testify to the consumption of immature specimens in both chronological periods. 
Despite the reduced amount of remains available it seems possible that the predominance of cattle may testify to the existence of a sedentary way of life.

Also, if we consider that each bovid weighs approximately 7 to 8 times more than each sheep or goat, the importance of cattle in the diet should be underlined. But the dominance of cattle in the day life of the Chalcolithic or the Iron Age communities is even greater if we consider the use of cattle for agriculture (ploughing) and for the transport of people and merchandises. In fact, the decline of the present-day autochtone races of cattle, recently observed, is the direct consequence of the decline of their use for those activities.
The importance of cattle at Palheiros may also result from role played by these animals in ceremonies and feasts.

Clear signs of hunting activities are not recorded. However, taking into account that it is currently accepted that systematic domestication of pig took place only under roman rule, it is possible that the identification of Sus might concern the wild species. We recall that wild boar and deer have been identified in other contemporaneous sites. However, hunting appears to have remained an unsystematic activity until the roman occupation, when it became a prestigious social activity (FERNÁNDEZ RodRÍGUEZ and PÉREZ ORTIZ 2005).

Table 5. Ubiquity of taxa identified by charcoal analysis, in the different areas of the settlement (LEP $=$ Lower Eastern Platform, UEP = Upper Eastern Platform, OEE = Outer Eastern Embankment, UNP = Upper Northern Platform, ONE $=$ Outer Northern Embankment, UCP = Upper Central Platform, LNP = Lower Northern Platform)

Tabela 5. Ubiquidade de taxa identificados através da análise de carvão vegetal, nas diferentes áreas do povoado (LEP= Plataforma Inferior Leste, $\mathrm{OEE}=$ Talude Exterior Leste, $\mathrm{UNP}=\mathrm{Plataforma}$ Superior Norte, $\mathrm{ONE}=$ Talude Exterior Norte, UCP=Plataforma Superior Central, LNP= Plataforma Inferior Norte).

\begin{tabular}{|c|c|c|c|c|c|c|c|c|c|}
\hline \multirow{2}{*}{$\begin{array}{c}\text { C. Palheiros - Charcoal } \\
\text { areas }\end{array}$} & \multicolumn{5}{|c|}{ Chalcolithic } & \multicolumn{4}{|c|}{ Iron Age } \\
\hline & LEP & UEP & OEE & UNP & ONE & OEE & LEP & UCP & LNP \\
\hline $\mathrm{n}^{\circ}$ samples studied & (13) & (6) & (2) & (4) & (7) & (8) & (31) & (2) & (11) \\
\hline Acer sp. & & & & & 1 & & & & \\
\hline Alnus glutinosa & 3 & 3 & 1 & & 4 & & & 1 & 3 \\
\hline Arbutus unedo & 10 & 4 & & 3 & 7 & 8 & 28 & 2 & 11 \\
\hline Cistaceae & 8 & 6 & 2 & 3 & 6 & 8 & 29 & 2 & 11 \\
\hline Daphne gnidium & & & & & & & 2 & & \\
\hline Erica arborea + Erica sp. & 11 & 5 & 2 & 4 & 6 & 8 & 28 & 2 & 11 \\
\hline Fabaceae & 2 & 2 & 2 & & 2 & 4 & 8 & & 6 \\
\hline Fraxinus angustifolia & 8 & 6 & & 1 & 6 & 3 & 10 & & 7 \\
\hline Labiatae & & & & & & & 1 & & \\
\hline Pinus pinaster / pinea & 7 & 5 & 1 & & 4 & 8 & 25 & 2 & 8 \\
\hline $\begin{array}{c}\text { Pinus type sylvestris } \\
\text { Pistacia sp. }\end{array}$ & & 2 & & & & 1 & 1 & & $\begin{array}{l}1 \\
1\end{array}$ \\
\hline Quercus (deciduous) & 8 & 2 & 2 & 1 & 6 & 7 & 11 & 1 & 6 \\
\hline Quercus (evergreen) & 12 & 6 & 2 & 1 & 7 & 6 & 20 & & 9 \\
\hline Quercus suber & 6 & 3 & & & 2 & 4 & 11 & 1 & 2 \\
\hline Rhamnus / Phillyrea & 2 & & & 1 & & 2 & 2 & & 1 \\
\hline Rosaceae Maloideae & 8 & 2 & & & 4 & & 1 & & \\
\hline Rubus cf. fruticosus & 1 & & & & & & & & \\
\hline cf. Sambucus sp. & & & & & & 1 & & & \\
\hline Vitis vinifera & & 1 & & & & & & & \\
\hline
\end{tabular}

\section{DISCUSSION AND CONCLUSIONS}

This brief presentation of data obtained with their archaeological, ecological and chronological significance, is not in itself particularly inspiring. In fact, and instead of talking of pottery, decoration, wheat, barley, beans, cattle, we should be talking of pans, pots, cups, bread, porridge, soup, stew, beef / veal, pork. Because, as previously pointed out by other authors (SHERRATT 1991), our ancestors didn't create a list of pottery shapes nor eat a list of animal and plant taxa; they produced instead pots and vessels; they also cooked meals.

One question must therefore be posed: "how was all this raw material transformed and later consumed? 


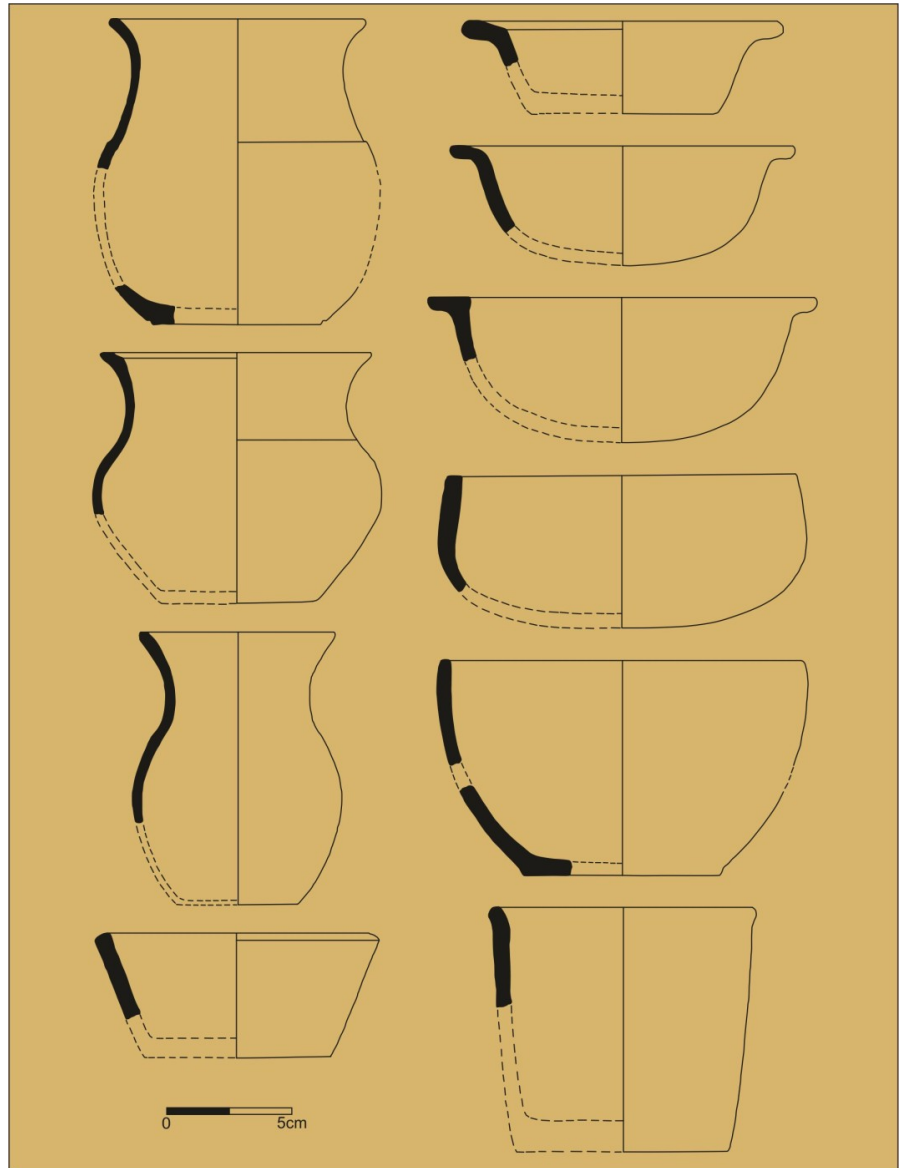

Fig. 5. Iron Age ceramic pots of small and medium size for cooking and consumption (bowls, beakers and vessels with "S" profile).

Fig. 5. Recipientes cerâmicos de pequeno e medio tamanho, para cozinhar e servir, da Idade do Ferro (PInTo 2011, 2, Est. CIII, CVII, CVIII, CXI, CXII, CXXVIII, adapted).

The first answer that comes to our mind is "by fire". Fire is needed to feed both kilns (pottery firing) and fireplaces (to cook food). This is why studying the fuel used by these populations, its abundance or shortage, becomes such an important issue. The analysis of charcoal fragments sampled at Crasto de Palheiros (and concerning both occupation moments) testifies to the surrounding vegetation, which was actively collected to supply daily needs (Table 5). The Mediterranean type vegetation comprised evergreen and deciduous Quercus, Arbutus, Pinus (pinaster / pinea and type sylvestris), Fabaceae, Erica, Cistaceae, Rosaceae, Salix, Fraxinus, Acer, Alnus, among others. Detailed charcoal results were presented elsewhere (FIGUEIRAL 2008). All plant taxa identified provided useful fire wood and timber; different habitats were exploited by human communities and the same pattern of plant exploitation characterises both occupation moments.

How were cereal grains transformed into eatable food? To start with, wheat and millet could be ground and baked into bread. However, flour obtained from both emmer and millet is only suitable for baking unleavened bread (galette). Only flour from free-threshing wheat is suitable for leavened bread. Bread made out of barley is dark, of poor texture and difficult to digest but its flour may be used more successfully as a kind of grouts ("pearl barley") for soup. Barley bread does not appeal to our modern tastes, but this might not have been the case for these populations. It must have been a matter of availability, taste and opinion as we can deduce for example from the descriptions of the kollix (spiral-shaped bun) made out of roughly milled barley. According to Hipponax a kollix was 'slave fodder'; Aristophanes considered it 'Boeotian staple' while Archestratus mentioned it as a 'Thessalian delicacy' (DALBY 2003).

Bread could be eaten as such or mixed in a kind of soup with other ingredients. Wheat and millet can also be mashed and mixed with boiled milk, being thus transformed into a mixture known as porridge (Fig. 5 and 6 ). In the absence of milk, porridge can also be made with water, in the same way as millet, which be cooked in water, like rice (LUNDSTROM-BAUDAIS and BAILLY 1995). Broad beans (and peas) can be eaten fresh or dried, cooked in soups and stews. It is quite possible that 
meat could be added to these stews, besides being roasted and / or boiled. The over fragmentation of bone fragments identified may testify to deliberate cooking practices allowing the release of bone marrow in stews; following the consumption of the at- tached meat, the small bones would be discarded and thrown in the fire (ANTUNES 1992; CARDOSO and COSTA 2004), which would explain their charred state. Over-charring of bone fragments is particularly important concerning the Iron Age remains.

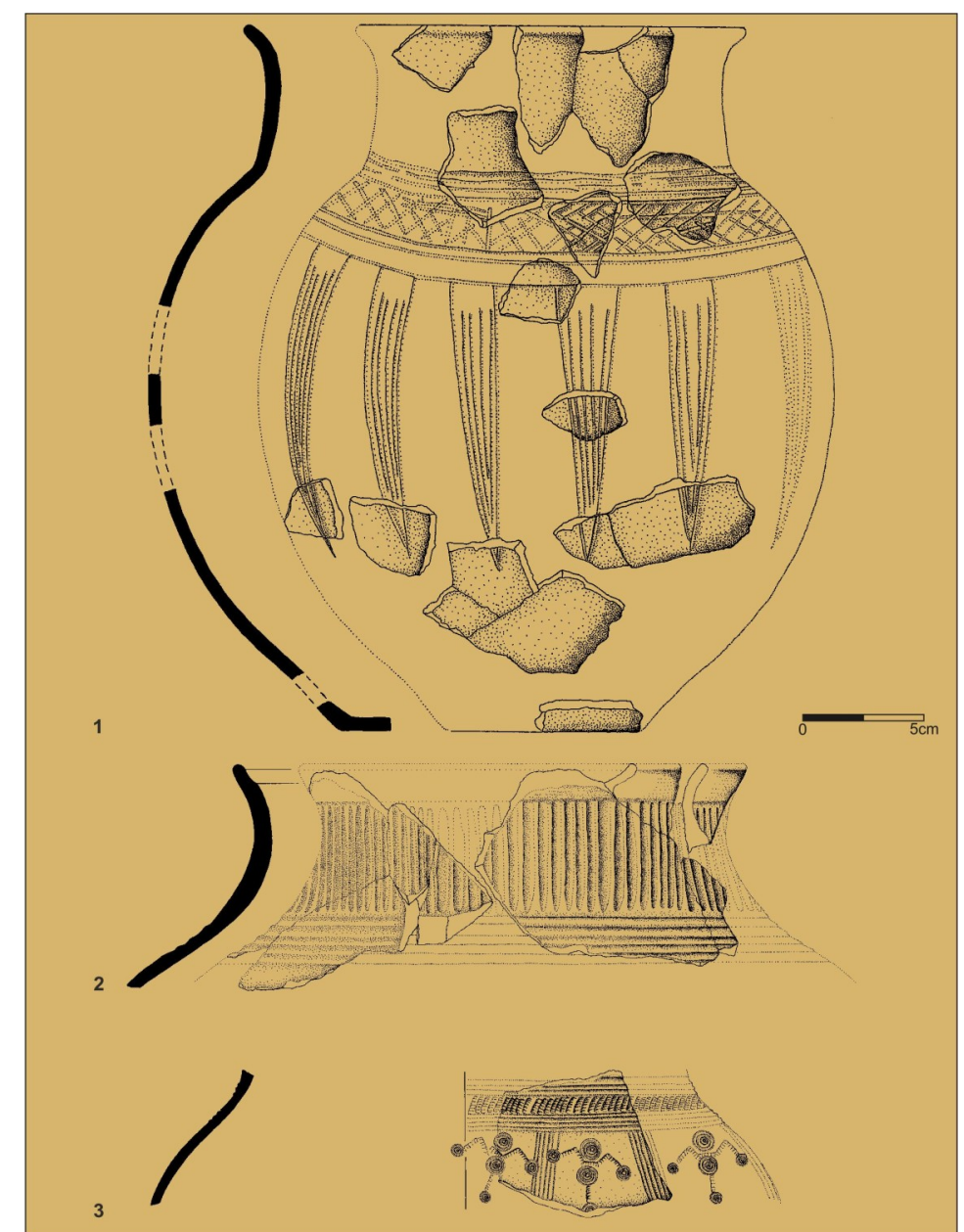

Fig. 6. Iron Age medium sized finely decorated ceramic containers (possibly used to serve liquids).

Fig. 6. Recipientes cerâmicos de tamanho médio, finamente decorados, da Idade do Ferro (usados possivelmente para server líquidos) (PINTO 2011, 2, Est. LX, LXVI, adapted).

From all the taxa identified juniper berries are the only likely seasoning used. However, small herbs like thyme (identified in the charcoal record) may also have been currently used, to lighten the monotony of everyday diet.

Are these food preparations/ cooking strategies likely to have been used at Palheiros? Does the pottery evidence support these suggestions?

Most of the vessels identified are s-shaped and round-shaped with a capacity until one litre and between $1-5 \mathrm{~L}$. Many present traces of having been used over the fire (AMORIM 1999; SANCHES 2016) (Fig. 5 and 6). This type of pot is perfectly adequate to the cooking of stews/soups/porridge.

Unleavened bread could be cooked over hot stones, directly in the middle of the embers, or just roasted/grilled over the fire. This practice leaves no identifiable archaeological traces. However, it is also possible that the low flat-based and thick walled dishes found in phase III might have been used for the same purpose.

Small vessels with specific shape and decoration could have been used as liquid containers or for drinking (AMORIM 1999) (Fig. 5 and 7). Also, during the Chalcolithic, the small Bell Beaker vessels could have been used for drinking as they never present any traces of fire.

This interpretation is supported by the analysis of surface residues recovered in vessels which suggest that bell beakers were used to drink beer or other fermented beverages (ROJO-GUERRA et al. 2006).

During the Iron Age, delicate S-shaped vessels with globular body may have been used as liquid containers (Fig. 6). These present a special 
glazing finish (AMORIM 1999; PINTO 2011), which makes them particularly suitable for this effect. The quality of their finish makes us wonder if they would be used regularly, or only during special occasions.

But what did they drink? According to the classical authors (STRABO y OROSIO, mentioned by
SCHULTEN 1958-1961) local Iron Age populations drank beer. This could have been made out of barley (or other malted cereals). Other fermented drinks, such as mead (fermented honey) may also have been consumed. This practice has been recognized in some Spanish sites (BuXó 1997).

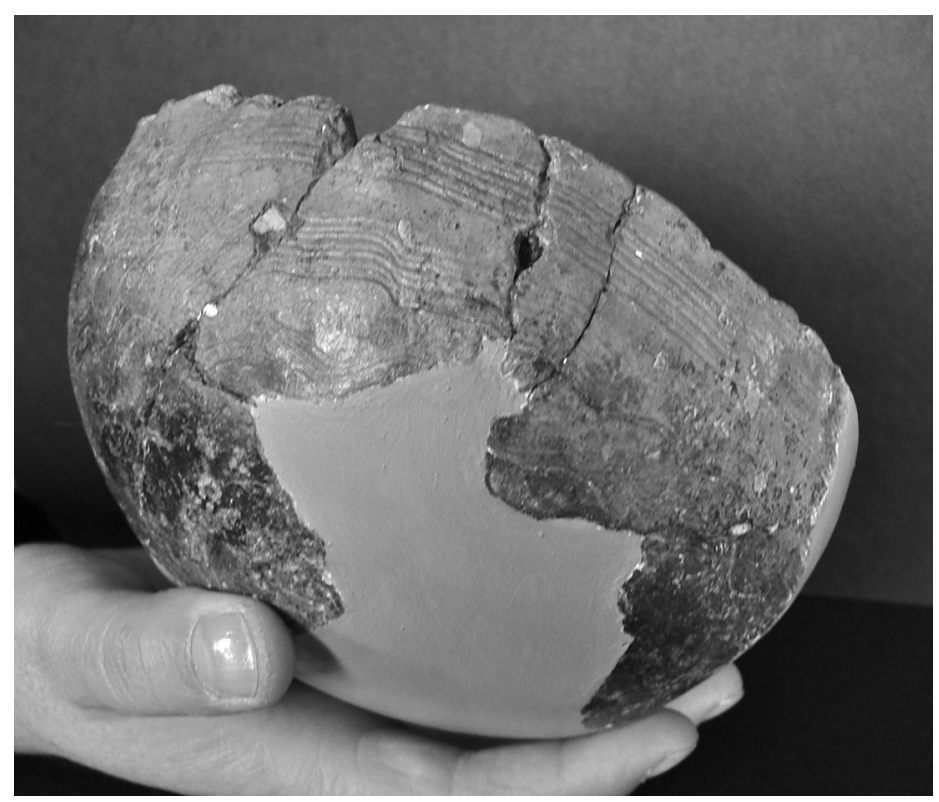

Fig. 7. Chalcolithic pot probably used for consumption of food.

Fig. 7. Recipiente calcolitico, usado presumivelmente para consume de alimentos.

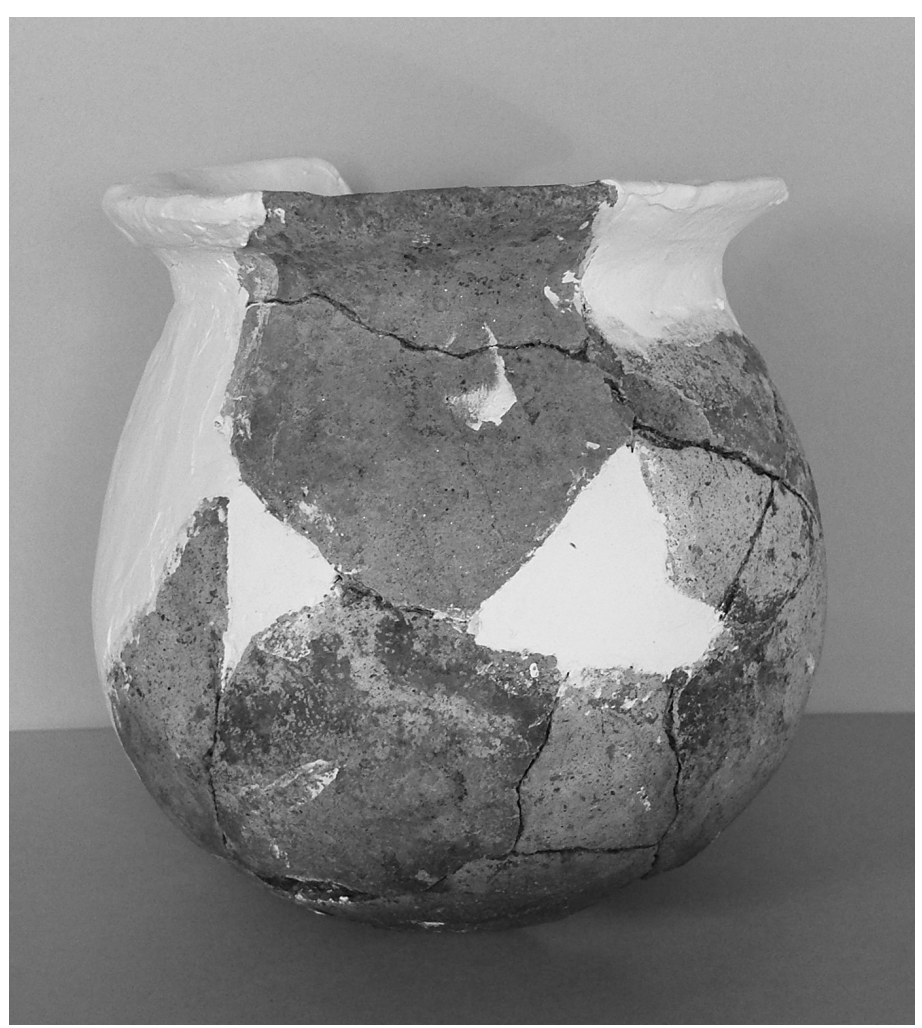

Fig. 8. Iron Age pot probably used to contain liquids.

Fig. 8. Recipiente da Idade do Ferro provavelmente usado para conter líquidos. 


\section{Food for thought}

As seen by our data, cereals and meat (mostly domestic animals) appear to have been the main components of local diet. The role of legumes is more difficult to assess due to preservation biases, but our results seem to confirm the major role played by Vicia faba during the Iron Age. The consumption of meat, however, has a meaning that goes far beyond taste and calories; other factors such as environment, society, economy and technology must also be taken into account. As seen from our data, cattle appear to have been the most important domesticated animal present during both periods, followed by Caprines (sheep and goat).

Data previously obtained in similar contexts from north-western Iberia and the Meseta, during Iron Age shows that the dominance of one or other of these elements depends on local environmental conditions and type of settlement (temporary or permanent, burial ground), (FERNÁNDEZ RODRÍGUEZ and PÉREZ ORTIZ 2005). However, at Crasto de Palheiros the importance of cattle, both in the $3^{\text {rd }}$ and $1^{\text {st }}$ millennia, goes against the local environmental conditions, eventually more favourable to Caprines. Cattle husbandry would have required a very strong commitment and must have represented a long lasting investment in a difficult ecosystem, where meadows are rare and sparse. So why were cattle such an important component of animal husbandry?

The consumption of meat, the production of milk ( + cheese and butter) as well as their use as traction animals and transport must have played an important role in this choice. However, we would like to draw attention to the fact that cattle may also have reached a special "social" status, as testified by the intentional burial of certain skeletal parts in Chalcolithic structures (SANCHES 2016). It is possible that, despite being used as a provider of food, cattle also played an important role in the mythological universe of local communities. Despite the fact that cattle was not depicted in rock and megalithic art (which are mainly abstract and/or schematic), the use of cow butter as a blending agent in the paintings of Dombate (La Coruña) (CARRERA RAMIREZ 2005) points to the possible social and cultural significance of these animals among local human communities, already during the $4^{\text {th }}$ millennium until the Roman times. In fact, the importance of cattle is stressed by their ritual use, in ceremonies and / or feasts along this large period of time.

Concerning the region where Palheiros is located, it is also interesting to notice that only very sparse remains of cattle have been recovered in other local Neolithic and Chalcolithic settlements, where Caprines dominate. This may be just one more sign pointing to the special status of this site, possibly as a regional centre interacting with different local communities, at least during the Chalcolithic. This hypothesis is supported by data from the Castanheiro do Vento (Foz Côa); this site, inter- preted as having had social and political functions similar to those of Palheiros, is also situated in an ecosystem favourable to Caprines; however abundant cattle remains have been recovered (CARDOSO and CosTA 2004).

At first sight, the overall picture emerging from the ecofacts may appear to be that of a relative similarity between the two millennia. However, at least concerning the plant world, the resemblance is most probably fictitious. In terms of wood resources, even if the plant spectrum remains the same, increased frequencies of scrub vegetation plants (legumes, heathers and Cistaceae) are noticed during the $1^{\text {st }}$ millennium, testifying to increasing human pressure (FIGUEIRAL 2005).

In terms of the material culture, "urban" changes reflect different technical and social roles, testifying to new ways of looking at / shaping the natural landscape. Food products used may have been similar but served distinct social and political purposes.

\section{ACKNOWLEDGEMENTS}

Maria de Jesus Sanches is part of the Research Project UID/HIS/04059/2013 (FCT) and this work was supported too by FEDER through the COMPETE 2020 ((POCI-010145-FEDER-007460). We are grateful to Luis Luis for authorizing the use of the map of Fig. 1 and to the two reviewers whose comments allowed us to greatly improve this manuscript.

\section{REFERENCES}

AmORIM, I.S.B. 1999.Crasto de Palheiros (Murça). As ocupações da Pré-Historia e da Proto-Historia na Plataforma Inferior. Dissertação de Mestrado, Faculdade de Letras, Porto.

Antunes, M. T. 1992. Povoados do Bronze Final da Beira Baixa - Alegrios, Moreirinha e Monte do Frade: elementos arqueozoológicos. Conimbriga, 31: 31-39.

Agroconsultores and CoBA (Eds) 1991. Carta dos Solos, Carta do Uso Actual da Terra e Carta de Aptidão da Terra do Nordeste de Portugal. UTAD, Vila Real.

Barbosa, S. C. P. 1999. O Crasto de Palheiros-Murça Contributo para o entendimento do fenómeno campaniforme em contexto doméstico no Norte de Portugal. Dissertação de Mestrado, Faculdade de Letras, Porto.

BuRILlo, F. 1983. El poblado de época ibérica y yacimiento medieval: Los Castellares (Herrera de los Navarros. Zaragoza). Institución Fernando el Católico,1, Zaragoza.

Buxó, R. 1997. Arqueología de las plantas. La explotación económica de las semillas y frutos en el marco mediterráneo de la Península Ibérica. Critica/ Arqueología, Hurope, Barcelona.

Buxó i Capdevila, R.; Alonso, N.; CAnal, D.; Echave, C. and GonZÁleZ, I. 1997. Archaeobotanical remains of hulled and naked cereals in the Iberian Peninsula. Vegetation Hist. and Archaeobot., 6: 1523 
CARdoso, J. L. 2005. Restos faunísticos do Crasto de Palheiros (Murça). Contributo para o conhecimento da alimentação no Calcolítico e na Idade do Ferro no Nordeste português. Portvgalia N.S., 26: 65-75.

CARdoso, J. L. and Costa, C. 2004. A study of the faunal assemblage from the prehistoric enclosure of Castanheiro do Vento (Vila Nova de Foz Côa). Journal of Iberian Archaeology, 6: 83-92.

Carrera Ramirez, F. 2005. El Arte Parietal en Monumentos Megalíticos del Noroeste Peninsular:Dimension del Fenómeno y Propuestas de Conservación. PhD Dissertation, Dep. Prehistoriay Arqueología Facultad de Geografia y Historia, Universidad Nacional de Educación a Distância.

Costa, J.C.; Aguiar, C.; Capelo, J.H.; Lousã, M. and Neto, C. 1998. Biogeografia de Portugal Continental. Quercetea, O, ALFA, FIP (Eds), Bragança.

CuBERo, C. 1994. La agricultura en la Edad de Hierro el el nornoreste de la Península Ibérica a partir del análisis paleocarpológico. $\mathrm{PhD}$ Dissertation, University Barcelona

DALBY, A. 2003. Food in the Ancient World, from $A$ to $Z$. Routledge, London and New York.

FERnÁndez Rodríguez, C. and PÉrez Ortiz, L. 2005. Caza y domesticación en el Noroeste de la Península Ibérica durante la Prehistória. Datos arqueozoológicos. In: S. O. Jorge, A. M. Bettencourt and I FigueIRAL (Eds.). A concepção das paisagens e dos espaços na Arqueologia da Península Ibérica. Universidad e do Algarve. Centro de Estudos do Património da Universidade do Algarve: 165-176.

Figueiral, I. 2008. Crasto de Palheiros (Murça, NE Portugal): a exploração dos recursos vegetais durante o $\mathrm{III}^{\circ}$ e $\mathrm{I}^{\circ}$ milénios. In: M. J. SANCHES (Ed.). O Cras to de Palheiros-Fragada do Crasto- MurçaPortugal. Municipio de Murça. Murça:79-108.

Hopf, M. 1987. Les débuts de l'agriculture et la diffusion des plantes cultivées dans la Péninsule Ibérique". In: J. Guilaine, (Eds.). Premières communautés paysannes de la Méditerranée occidentale. CNRS, Paris :267-274

Jarvis, A., H. I. Reuter, A. Nelson, and E. Guevara. 2008. Hole-filled SRTM for the globe, Version 4 available from the CGIAR-CSI SRTM 90m Database. (Available online at http://srtm.csi.cgiar.org).

LundSTROM-BAUDAIS, K. and BAILLY, G. 1995. In the cellar of a wine-maker during the $14^{\text {th }}$ century: the archaeobotanical study of Ilôt Vignier, Besançon (France). In H. Kroll, R. PASTERnAK, (Eds.), Res Archaeobotanicae, Proc. $9^{\text {th }}$ Symposium IWGP, Kiel : 165-193.

Morais, P. R. 2008. Artefactos líticos do Crasto de Palheiros. In: M. J. SANCHES (Eds.). O Crasto de Palheiros-Fragada do Crasto- Murça-Portugal. Município de Murça. Murça:134-141.

PEÑA ChOCARRO, L. 1992. Los modelos etnográficos en Arqueobotánica: los cereals vestidos. I Jornadas Internacionales sobre Tecnologia Agraria Tradicional. Museo Nacional del Pueblo Español, Madrid:21-29

PeÑA ChOCARro, L. 1995. Prehistoric agriculture in southern Spain during the Neolithic and the Bronze Age: the application of ethnographic models. PhD dissertation, Institute of Archaeology, University College, London.
PInTO, D. B. 2008. Artefactos metálicos do Crasto de Palheiros. In: M. J. SANCHES (Ed.). O Crasto de Palheiros-Fragada do Crasto- Murça-Portugal. Municipio de Murça. Murça: 142-150 and Fig. II.30, Fig. II.31.

PINTO, D. B. 2011. O Crasto de Palheiros na Idade do Ferro. Contributo da aplicação de uma nova metodologia no estudo da cerâmica. Tese de Doutoramento. Faculdade de Letras da UC. Coimbra.

PINTO da Silva, A. 1988. A paleoetnobotânica na arqueologia portuguesa. Resultados desde 1931 a 1987 . In F. QueIroga, I. SousA, C. Oliveira (Eds). Paleoecologia e Arqueologia. Câmara Municipal de Vila Nova de Famalicão, :13-29.

QueIRogA, F.M.V.R. 2003. War and Castros. New approaches to the northwestern Portuguese Iron Age. BAR International Series 1198.

RiBeIRo, A. 1974. Contribution à l'Etude Tectonique de Trás-os-Montes Orientale. Serv. Geol. de Portugal. Lisboa.

Rodríguez López, C.M., FERnÁNdeZ RodríGuez, C. , RAMIL REGO, P. .1993. El aprovechamiento del medio natural en la cultura castreña de Noroeste peninsular.Trabalhos de Antropologia e Etnologia, 33, 1-2 : 285-306 [Actas $1^{\circ}$ Congresso de Arqueologia Peninsular]

RoJo-Guerra, M.Á., GARrido-PENA, R., GARCIAMARTINEZ-DE-LAGRAN, Í., JUAN-TRESERRAS, J., Matamala, J.C., 2006. Beer and Bell Beakers: Drinking Rituals in Copper Age Inner Iberia. Proceedings of the Prehistoric Society, 72: 243-265.

SANCHES, M. J. 2016.Animal bones, seeds and fruits recovered from Crasto de Palheiros. A contribution to the study of diet and commensality in the recent PreHistory and Iron Age of Northern Portugal". In: R. VILAÇA \& M. SERRA, eds. To feed the body, to nourish the soul, to create sociability. Food and commensality in pre and protohistoric societies. CEPBA\&IAFLUC\&Palimpsesto:79-119.

SANChES, M. J. 1997. Pré-história Recente de Trás-osMontes e Alto Douro. SPAE [Textos,1]. Porto

SAnches, M. J. and PINTO, D. B 2005. O Crasto de Palheiros (Norte de Portugal). Notas sobre um povoado protohistórico em Trás-os-Montes. Procc. Colóquio " O Castro - um lugar para habitar". Cadernos do Museu. Penafiel, 11:55-74.

SANCHES, M. J. and PINTO, D. B. 2008a.The architectural transformation of the Fragada do Crasto, or Crasto de Palheiros, from the beginning of the 3rd millenium $\mathrm{BC}$ to the beginning of the 2 nd century $\mathrm{AD}$ In: M. J. SANChes (Eds.). O Crasto de PalheirosFragada do Crasto- Murça-Portugal. Municipio de Murça. Murça:21-38.

SANChES, M. J. and PINTO, D. B. 2008b. Cronologia e faseamento do Crasto de Palheiros em I, II e III". In: M. J. SANChes (Ed.). O Crasto de Palheiros-Fragada do Crasto- Murça-Portugal. Municipio de Murça. Murça:39-53.

SANChES, M.J.; NunES, S.A. and PINTO, D. P. 2005.Trás-osMontes (Norte de Portugal). As gentes e os ecossistemas, do Neolítico à Idade do Ferro. In: S. O. Jorge, A. M. Bettencourt and I. Figueiral (Eds.). A concepção das paisagens e dos espaços na Arqueologia da Península Ibérica. Universidad e do 
Algarve. Centro de Estudos do Património da Universidade do Algarve: 189-206.

SCHULTEN, A. 1958-61. Geografia y Etnografia antiguas de la Peninsula Ibérica. Madrid.

SeABra, L.C.N. 2015. Estudo Paleoetnobotânico do Povoado da Idade do Ferro do Crastoeiro (Noroeste de Portugal), Tese Mestrado, Universidade do Minho, Braga.

SigaUt, F. 1988. A method for identifying grain storage techniques and its application for European agricultural history. Tools and Tillage, 6 (1): 3-32.

StUiver, M. and Reimer, P. J. , 1993: "Extended C14 database and revised CALIB radiocarbon calibration program. Radiocarbon, 35: 215-230.

Tereso, J.; Ramil-Rego, P.; AlmeidA-DA-Silva, R. 2013. Roman agriculture in the conventus Bracaraugustanus (NW Iberia). Journal of Archaeological Science, 40(6): 2848-2858. doi:http:// dx.doi.org/10.1016/j.jas.2013.01.006
TABORDA, V. 1987. Alto Trás-os-Montes. Estudo geográfico. Livros Horizonte, Lisboa.

AAVV. 2008. O Crasto de Palheiros-Fragada do CrastoMurça-Portugal. SANCHES, M. J. (Eds) Municipio de Murça. Murça.

Vaz, F.G.; Tereso, J. P.; Pereira J.A. and Pereira S.S., in press. O potencial interpretativo dos contextos secundarios e terciarios: o caso do estudo arqueobotânico de Chã (Alfândega da Fé)". Cadernos do GEEvH

ZoHARY, D. and Hopf M. 2004. Domestication of Plants in the Old World. Oxford University Press, 3rd (ed) 